\section{Seasonal Variation in the Response of 'Valencia' Orange to Two Abscission Compounds}

\author{
U. Hartmond, J.D. Whitney, J.K. Burns, and W.J. Kender ${ }^{1}$ \\ University of Florida, Institute for Food and Agricultural Sciences, Citrus \\ Research and Education Center, 700 Experiment Station Road, Lake Alfred, \\ FL 33850-2299
}

Additional index words. bloom, Citrus sinensis, CMN-pyrazole, defoliation, fruit detachment force, mechanical harvest, metsulfuron-methyl, phytotoxicity

\begin{abstract}
Two field studies were conducted to evaluate the effect of metsulfuron-methyl and 5-chloro-3-methyl-4-nitro-1 H-pyrazole (CMN-pyrazole) on abscission of 'Valencia' orange [Citrus sinensis (L.) Osbeck] during the 3-month harvest season. Solutions of metsulfuron-methyl at $0.5,1$, and $2 \mathrm{mg} \cdot \mathrm{L}^{-1}$ active ingredient (a.i.) were applied at 10-day intervals beginning on 13 Feb. and ending 18 May 1998. Early in the harvest season, 1 or $2 \mathrm{mg} \cdot \mathrm{L}^{-1}$ metsulfuron-methyl significantly reduced fruit detachment force (FDF) 14 days after application. Metsulfuron-methyl was less effective during a 4- to 6-week period following bloom ("less-responsive period"). After this period, metsulfuron-methyl regained the ability to loosen fruit. Applications of $2 \mathrm{mg} \cdot \mathrm{L}^{-1}$ a.i. were more effective than 1 $\mathrm{mg} \cdot \mathrm{L}^{-1}$ in reducing FDF and causing leaf drop, but $0.5 \mathrm{mg} \cdot \mathrm{L}^{-1}$ a.i. had little or no effect on FDF. Flowers and leaflets on developing shoots and young fruit completely abscised with 1 and $2 \mathrm{mg} \cdot \mathrm{L}^{-1}$ a.i. Defoliation and twig dieback was extensive at all concentrations and spray dates, eliminating metsulfuron-methyl as a commercially viable abscission agent for citrus. In a separate experiment $\mathrm{CMN}$-pyrazole at 50 and $100 \mathrm{mg} \cdot \mathrm{L}^{-1}$ a.i. and metsulfuronmethyl at $0.5 \mathrm{mg} \cdot \mathrm{L}^{-1}$ a.i. were applied to 'Valencia' trees to determine fruit removal with a trunk shake and catch harvesting system. Application of both abscission materials before and after the "less-responsive period" resulted in a $10 \%$ to $12 \%$ increase in fruit removal when compared to control trees. Less than a 35\% reduction in FDF was sufficient to

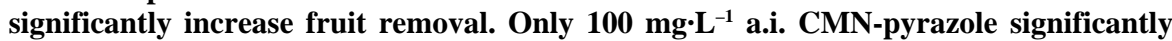
increased fruit removal when applied during the "less-responsive period." Chemical names used: Methyl-2-(((((4-Methoxy-6-Methyl-1,3,5-Triazin-2-yl)-Amino)Carbonyl) Amino)Sulfonyl)Benzene (Metsulfuron-methyl); 5-Chloro-3-methyl-4-nitro-1- $\mathrm{H}$-pyrazole (CMN-pyrazole).
\end{abstract}

The use of abscission materials to aid in mechanical harvesting of citrus destined for juice processing has been tested for two decades with varying success (Brown, 1998; Whitney and Harrell, 1989). Most compounds gave inconsistent fruit loosening or caused unacceptable losses of leaves, flowers, and young fruits (Whitney, 1995). One compound, 5-chloro-3-methyl-4-nitro- $1 \mathrm{H}$-pyrazole (CMN-pyrazole, 'Release', Abbott Laboratories, Chicago) was extensively tested in the earlier Florida citrus abscission program (Biggs and Kossuth, 1980; Holm and Wilson, 1977). It was selective for mature fruit, caused no canopy injury and loosened fruit within 3 to 5 $\mathrm{d}$ of application. Despite this favorable mode

Received for publication 19 Jan. 1999. Accepted for publication 9 Aug. 1999. Florida Agricultural Experiment Station, Journal Series No. R-06721. Funding for this study was provided in part by the Florida Dept. of Citrus. We gratefully acknowledge the technical assistance of Angela Grant, Wu Houjiu, Karen Colston, and David Noxel in conducting the experiments. The cost of publishing this paper was defrayed in part by the payment of page charges. Under postal regulations, this paper therefore must be hereby marked advertisement solely to indicate this fact. ${ }^{1}$ To whom reprint requests should be addressed (email: kender@lal.ufl.edu). of action, $\mathrm{CMN}$-pyrazole was never registered for use, largely because of economic concerns, and was subsequently abandoned. A satisfactory abscission material for citrus has not been developed and marketed.

The success of an abscission chemical for citrus is dependent on its ability to selectively loosen mature fruit with minimal phytotoxic effects. This is particularly important for 'Valencia', a widely grown, late-season, processing variety. The harvesting season for 'Valencia' fruit usually begins in February and extends through May. During this time, growing shoots, flowers, and young developing fruit are found on trees at the same time. Abscission materials for use on 'Valencia' must not injure young fruit and tender tissues associated with flowering and new growth. In addition, mature 'Valencia' fruit become less responsive to abscission materials shortly after bloom (Wheaton et al., 1977). This "lessresponsive period" may last for 2 to 6 weeks. Fluctuations in fruit detachment force (FDF) occur throughout the 'Valencia' harvest season (Holm and Wilson, 1977), suggesting that fruit maturity may play a role in response to abscission materials. To be commercially useful, an abscission material must overcome the "less-responsive period" after bloom in
'Valencia' and the effect of fruit maturity on abscission response.

Recently, Wilcox and Taylor $(1996,1997)$ reported that sulfonylureas and imidazolinones have abscission activity on citrus fruit. These compounds can be used at relatively low application rates and are registered for herbicidal use on many agronomic crops. We reported that high temperatures adversely affected performance of these compounds in citrus and that applications in solutions with low $\mathrm{pH}$ increased fruit ethylene production (Burns et al., 1999). We also tested the response of a wide range of citrus cultivars to metsulfuronmethyl (a sulfonylurea) and demonstrated the potential for utilizing this compound for abscission (Kender et al., 1999).

In this study, a series of field tests were conducted to examine the effect of metsulfuronmethyl on abscission and phytotoxicity of 'Valencia' orange fruit and trees throughout the harvest season. In a separate test, we compared fruit removal with a mechanical harvesting system (trunk shaker) on trees sprayed with metsulfuron-methyl with that of trees sprayed with CMN-pyrazole before, during, and after the "less-responsive period."

\section{Materials and Methods}

Two sets of field experiments were conducted with 'Valencia' orange trees in groves at the Citrus Research and Education Center, Lake Alfred, Fla., during the 1998 harvest season. Trees were grown on sour orange rootstock in Candler fine sand soil at $4.5-\mathrm{m} \times$ 6.0-m spacing (358 trees/ha).

In the first series of tests, 9-year-old trees with canopies $3 \mathrm{~m}$ in height and $2.7 \mathrm{~m}$ in diameter, yielding $80 \mathrm{~kg}$ of fruit, were sprayed with metsulfuron-methyl (Ally®, Dupont Co., Wilmington, Del.). We used a 50-L field sprayer (R\&D Sprayers, Opelousas, La.) equipped with a 2-m spray boom (six nozzles, total output of $3.3 \mathrm{~L} \cdot \mathrm{min}^{-1}$ ), which was held vertical while encircling the tree to ensure uniform spray coverage. Starting on 13 Feb. and ending on 18 May 1998, spray solutions were applied at a rate of $5 \mathrm{~L} /$ tree $\left(1850 \mathrm{~L} \cdot \mathrm{ha}^{-1}\right)$ at concentrations of 0 (control) or $2 \mathrm{mg} \cdot \mathrm{L}^{-1}$. Tests were conducted at 10-d intervals, spraying three replicate trees per treatment on each date. A total of 10 spray treatments were applied during the harvest season. After observing excessive phytotoxicity with the 2 $\mathrm{mg} \cdot \mathrm{L}^{-1}$ treatment, concentrations of 1 and 0.5 $\mathrm{mg} \cdot \mathrm{L}^{-1}$ were added starting $16 \mathrm{Mar}$. and 17 Apr., respectively. All spray solutions included $0.125 \%$ of the adjuvant Kinetic ${ }^{\circledR}$ (proprietary mix of $25 \%$ organosilicone and $75 \%$ nonionic oil; Setre Chemical Co., Memphis, Tenn.) and were buffered with Buffer Xtra Strength ${ }^{\circledR}$ (proprietary mix of organic phosphatic acids, Setre Chemical Co.) to adjust the $\mathrm{pH}$ to 6.5.

Before treatment, the ground under each canopy was cleared of plant debris. Counts of mature fruit drop were taken twice per week for 3 weeks following spray application. All remaining fruit were harvested $21 \mathrm{~d}$ after spraying to determine yield and percentage of fruit drop. Leaf loss was determined by weighing 
leaf material accumulated under trees after 21 d. Overall injury to the canopy (defoliation and twig dieback) was graded visually 21 and $60 \mathrm{~d}$ after application using a scale from 0 (no injury) to 10 (representing $100 \%$ defoliation). Spray effects on the new developing crop (fruit set and immature fruit loss) were rated $60 \mathrm{~d}$ after spray by estimating crop load relative to the full crop on the control. The FDF was measured weekly using a Force Five pullforce gauge (Wagner Inst., Greenwich, Conn.) on a sample of 10 fruit clipped from each tree. To account for preharvest fruit drop, we calculated a weighted average from the measured FDF (in kilograms) for on-tree fruit and mean fruit weight for the proportion of fruit that had dropped.

In the second set of experiments, we tested the effects of metsulfuron-methyl and CMNpyrazole on fruit removal with a mechanical harvesting system. Ten-year-old trees $(3.6 \mathrm{~m}$ in height, $3 \mathrm{~m}$ in diameter, $200-\mathrm{kg}$ yield) were sprayed with metsulfuron-methyl at 0 or 0.5 $\mathrm{mg} \cdot \mathrm{L}^{-1}$ a.i., or CMN-pyrazole at 50 or 100 $\mathrm{mg} \cdot \mathrm{L}^{-1}$ a.i. Solutions included the adjuvant and buffer. On 15 Apr., 1 May, and 18 May 1998, a gas-powered, single-nozzle handgun sprayer was used to apply $19 \mathrm{~L}$ per tree $(7000$ $\mathrm{L} \cdot \mathrm{ha}^{-1}$ ) of spray solution to three replicate trees per treatment on each date. Fruit drop was monitored to determine optimal harvesting time for each treatment to avoid significant preharvest drop. The FDF was measured prior to harvest 3 to $10 \mathrm{~d}$ after spraying. Trees were mechanically harvested with an experimental Compton monoboom trunk shaker (Compton Enterprises, Chico, Calif.) operated for $5 \mathrm{~s}$ at 6 $\mathrm{Hz}$ and $4.5 \mathrm{~cm}$ displacement. Fruit removal was determined by comparing the weight of fruit that was dropped by the shaker to that of fruit remaining on the tree. The number of immature fruit lost due to shaking was recorded. Leaf loss and canopy injury was determined visually 3 weeks after spray applications.

In all experiments, fruit maturity was measured at application time using standard juice analysis procedures for soluble solids (hand refractometer) and titratable acids (Wardowski et al., 1995).

Data were computed and, when applicable, transformed or correlated using MS-Excel ${ }^{\circledR}$ spreadsheet functions (Microsoft, Redmond, Wash.). Analysis of variance of each experiment and regressions were performed using the GLM and REG procedures of the SAS statistical package (SAS Institute, Cary, N.C.). Means were separated by Duncan's multiple range test at $P \leq 0.05$.

\section{Results}

Fruit loosening and fruit drop. After application of metsulfuron-methyl, reduction of FDF and increase in fruit drop generally followed the pattern shown in Fig. 1. Significant reduction in FDF was measured $7 \mathrm{~d}$ after application of either $0.5,1.0$, or $2.0 \mathrm{mg} \cdot \mathrm{L}^{-1}$ (Fig. 1A). The FDF continued to decrease throughout the 3-week period and differences were most striking $14 \mathrm{~d}$ after application of 2.0

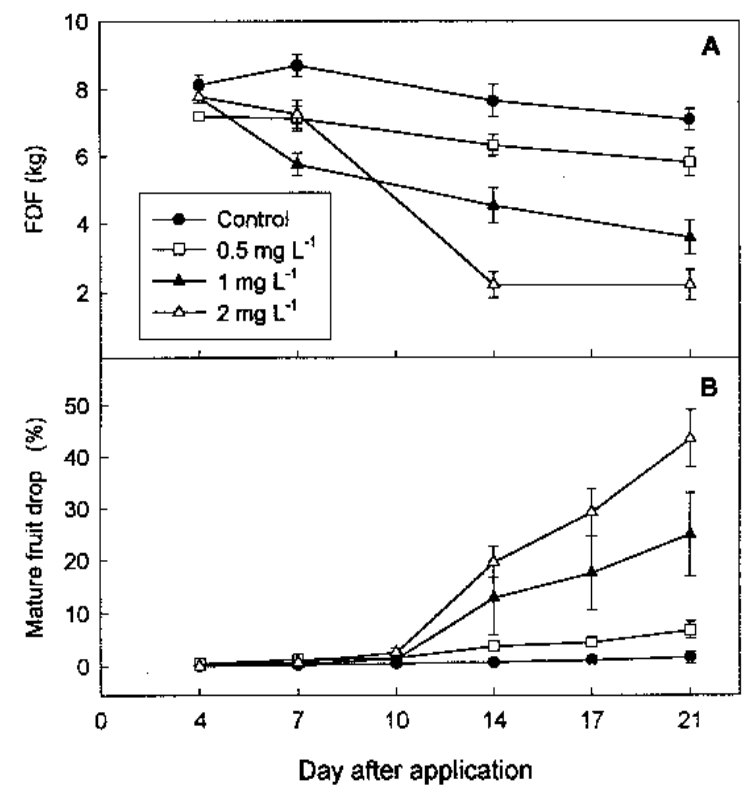

Fig. 1. (A) Reduction in fruit detachment force (FDF), and (B) cumulative percentage of mature fruit drop following application of metsulfuron-methyl. Valencia trees were sprayed with metsulfuron- methyl at $0,0.5,1$, and $2 \mathrm{mg} \cdot \mathrm{L}^{-1}$ at $1870 \mathrm{~L} \cdot \mathrm{ha}^{-1}$ at the onset of the less-responsive period (17 Apr. 1998). Bars indicate SE.

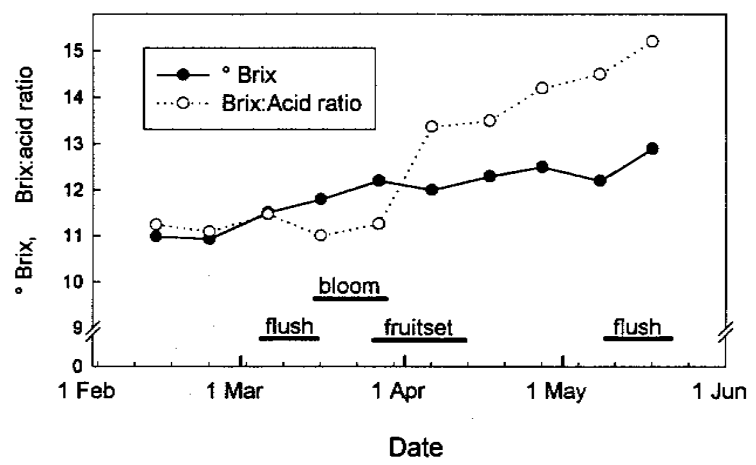

Fig. $2{ }^{\circ}$ Brix, ${ }^{\circ}$ Brix to $\%$ acid ratio, and timing of vegetative and reproductive events during the 'Valencia' harvest season in Lake Alfred, Fla., 1998.

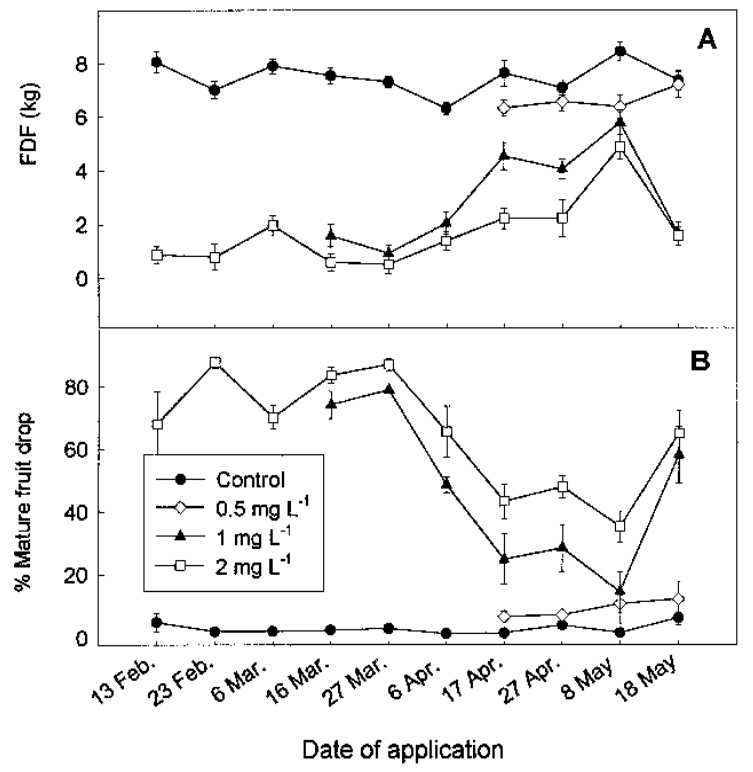

Fig. 3. Effect of application time and concentration of metsulfuron-methyl on (A) fruit detachment force (FDF) after $14 \mathrm{~d}$, and (B) cumulative percentage of mature fruit drop after $21 \mathrm{~d}$. Bars indicate sE. 
$\mathrm{mg} \cdot \mathrm{L}^{-1}$. In general, increasing amounts of metsulfuron-methyl resulted in greater reduction in FDF $14 \mathrm{~d}$ after application. Reduction in FDF did not change significantly between 14 and $21 \mathrm{~d}$ after application. The increase in percent cumulative fruit drop (Fig. 1B) followed the decrease in FDF. Cumulative fruit drop 14, 17, and $21 \mathrm{~d}$ after application increased with the concentration of metsulfuronmethyl applied.

Maturity effects. Brix/acid ratio increased from late March to mid May (Fig. 2). During this period, two cycles of flushing shoots were observed beginning in early March and early May. Bloom was extended over $>3$ weeks beginning in mid-March, after which fruit set and young fruit development began.

Over the 3-month harvest season, trees responded variably to metsulfuron-methyl(Fig. 3 ). Prior to and during bloom, $2 \mathrm{mg} \cdot \mathrm{L}^{-1}$ applications reduced FDF to $<20 \%$ of that of the control $14 \mathrm{~d}$ after application, and $70 \%$ to $90 \%$ of the mature fruit dropped within a 3-week period. After fruit set began, $2 \mathrm{mg} \cdot \mathrm{L}^{-1}$ became less effective at reducing FDF (Fig. 3A) and inducing abscission (dropping fruit) (Fig. 3B). After the 8 May application, fruit abscission in response to $2 \mathrm{mg} \cdot \mathrm{L}^{-1}$ improved again. Reduction in effectiveness after bloom was also observed with $1.0 \mathrm{mg} \cdot \mathrm{L}^{-1}$, and abscission improved by the last application date (Fig. $3 \mathrm{~A}$ and B). Applications of $0.5 \mathrm{mg} \cdot \mathrm{L}^{-1}$ were not effective in reducing FDF or increasing fruit drop.

Phytotoxicity, nonspecificity and "less-responsive period." Application of 1.0 and 2.0 $\mathrm{mg} \cdot \mathrm{L}^{-1}$ metsulfuron-methyl resulted in significant leaf drop (Fig. 4A). Defoliation became evident 10 to $14 \mathrm{~d}$ after application and continued well past $21 \mathrm{~d}$ (Fig. 4 B). Leaf loss was greater when trees were sprayed before bloom. After this date, metsulfuron-methyl-induced leaf drop decreased, but increased again with the last two spray applications. Although substantially less defoliation was induced with 0.5 $\mathrm{mg} \cdot \mathrm{L}^{-1}$, leaf loss remained greater than in the control. Twig dieback, progressing down from the apical bud, was observed with all metsulfuron-methyl applications but was most severe with applications of 1.0 and $2.0 \mathrm{mg} \cdot \mathrm{L}^{-1}$ (data not shown).

When $2.0 \mathrm{mg} \cdot \mathrm{L}^{-1}$ was applied to trees before flowering, subsequent fruit set was strongly reduced, resulting in $>40 \%$ crop reduction (Fig. 4C). Applications of 2.0 or $1.0 \mathrm{mg} \cdot \mathrm{L}^{-1}$ during bloom resulted in complete floral abscission. After bloom, these treatments resulted in near-complete abscission of young developing fruit. Drop of young fruit was less affected during the "less-responsive period," but then increased following the later spray dates. A similar trend in crop reduction was observed following $0.5 \mathrm{mg} \cdot \mathrm{L}^{-1}$ metsulfuron-methyl.

In contrast to metsulfuron-methyl treatments, $\mathrm{CMN}$-pyrazole treatments caused very little defoliation, no twig dieback, and no immature fruit abscission. Fruit on trees sprayed with CMN-pyrazole had comparable or lower FDF values than those on trees treated with 0.5 $\mathrm{mg} \cdot \mathrm{L}^{-1}$ metsulfuron-methyl (Table 1 ).

Mechanical fruit removal. Fruit removal

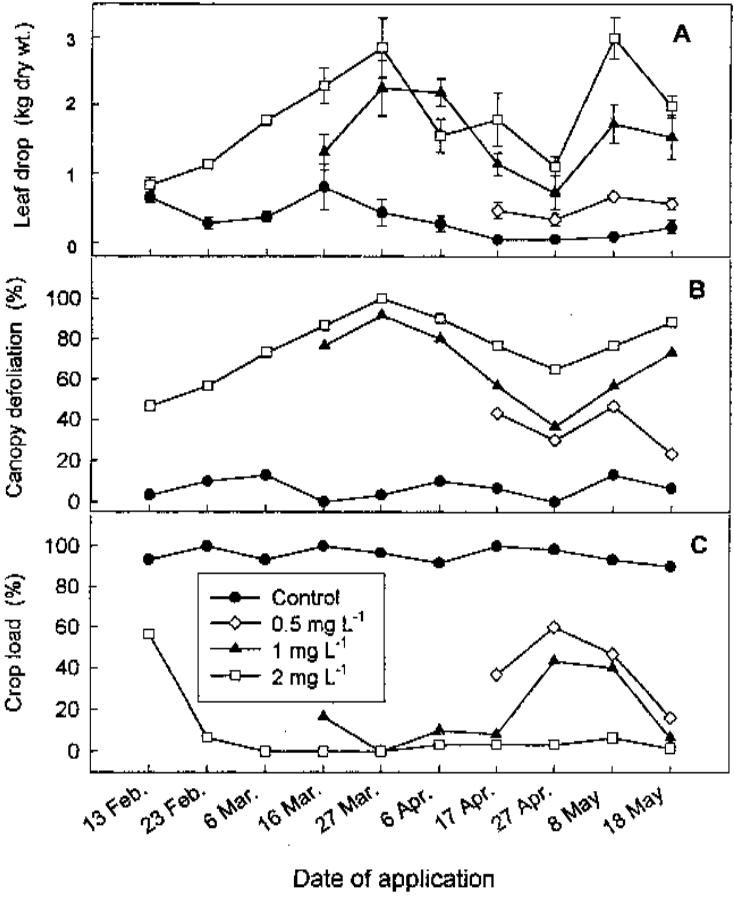

Fig. 4. Effect of application time and concentration of metsulfuron-methyl on (A) leaf drop after $21 \mathrm{~d}$, and on (B) estimated canopy defoliation and (C) crop load (young fruit) after $60 \mathrm{~d}$. Bars in (A) indicate SE.

Table 1. Effect of metsulfuron-methyl or CMN-pyrazole $\left(7000 \mathrm{~L} \cdot \mathrm{ha}^{-1}\right)$ on fruit detachment forces (FDF), and removal of mature and young 'Valencia' orange fruit with a trunk shaker during the harvest season of 1998 in Lake Alfred, Fla.

\begin{tabular}{|c|c|c|c|c|c|c|}
\hline $\begin{array}{l}\text { Spray } \\
\text { date }\end{array}$ & $\begin{array}{c}\text { Harvest } \\
\text { date }\end{array}$ & Treatment & $\begin{array}{l}\text { Concn } \\
\left(\mathrm{mg} \cdot \mathrm{L}^{-1}\right)\end{array}$ & $\begin{array}{l}\text { FDF } \\
(\mathrm{kg})\end{array}$ & $\begin{array}{c}\text { Mature fruit } \\
\text { removal } \\
(\%)\end{array}$ & $\begin{array}{l}\text { Young fruit } \\
\text { removal } \\
\text { (No./tree) }\end{array}$ \\
\hline \multirow{4}{*}{15 Apr. } & 20 Apr. & Control & -- & $10.3 \mathrm{a}^{\mathrm{z}}$ & $85.6 \mathrm{~b}$ & $n d^{y}$ \\
\hline & 24 Apr. & Metsulfuron-m. ${ }^{\mathrm{x}}$ & 0.5 & $8.59 \mathrm{~b}$ & $95.8 \mathrm{a}$ & nd \\
\hline & 20 Apr. & CMN-pyrazole & 50 & $5.04 \mathrm{c}$ & $93.8 \mathrm{ab}$ & nd \\
\hline & 20 Apr. & CMN-pyrazole & 100 & $2.14 \mathrm{~d}$ & $98.7 \mathrm{a}$ & nd \\
\hline \multirow[t]{4}{*}{1 May } & 7 May & Control & --- & $10.4 \mathrm{a}$ & $87.8 \mathrm{~b}$ & $17 \mathrm{~b}$ \\
\hline & 12 May & Metsulfuron-m. & 0.5 & $10.3 \mathrm{a}$ & $83.2 \mathrm{~b}$ & $42 \mathrm{a}$ \\
\hline & 7 May & CMN-pyrazole & 50 & $9.48 \mathrm{a}$ & $87.5 \mathrm{~b}$ & $19 \mathrm{~b}$ \\
\hline & 7 May & CMN-pyrazole & 100 & $7.80 \mathrm{~b}$ & $95.3 \mathrm{a}$ & $18 \mathrm{~b}$ \\
\hline \multirow[t]{4}{*}{18 May } & 21 May & Control & --- & $10.5 \mathrm{a}$ & $79.7 \mathrm{~b}$ & $35 \mathrm{a}$ \\
\hline & 22 May & Metsulfuron-m. & 0.5 & $8.04 \mathrm{~b}$ & $88.1 \mathrm{ab}$ & $22 \mathrm{a}$ \\
\hline & 21 May & CMN-pyrazole & 50 & $6.85 \mathrm{~b}$ & $92.4 \mathrm{a}$ & $19 \mathrm{a}$ \\
\hline & 21 May & CMN-pyrazole & 100 & $2.84 \mathrm{c}$ & $95.5 \mathrm{a}$ & $36 \mathrm{a}$ \\
\hline
\end{tabular}

${ }^{2}$ Mean separation of data within columns and experiments by Duncan's multiple range test at $P \leq 0.05$ ${ }^{\mathrm{y}}$ Not determined prior to fruit set.

${ }^{\mathrm{x}}$ Metsulfuron-methyl.

with a trunk shaker was significantly improved by 50 and $100 \mathrm{mg} \cdot \mathrm{L}^{-1} \mathrm{CMN}$-pyrazole when compared to control trees (Table 1). Application of $0.5 \mathrm{mg} \cdot \mathrm{L}^{-1}$ metsulfuron-methyl increased fruit removal significantly only after the 15 Apr. application, despite the higher amount of a.i. applied with $7000 \mathrm{~L} \cdot \mathrm{ha}^{-1}$ vs. $1850 \mathrm{~L} \cdot \mathrm{ha}^{-1}$ used in the first set of experiments. The FDF was reduced with either abscission material before (15 Apr.) or after (18 May) the "less-responsive period." After the 1 May application, significant reductions in FDF occurred only when trees were sprayed with 100 $\mathrm{mg} \cdot \mathrm{L}^{-1} \mathrm{CMN}-$ pyrazole. Despite large reductions in FDF in some cases, a $17 \%$ to $35 \%$ decrease was necessary to achieve the highest fruit removal using this mechanical harvest system. Young fruit loss was generally low as a result of trunk shaking.

\section{Discussion}

Metsulfuron-methyl was very effective in loosening mature 'Valencia' fruit. The FDF decreased and fruit drop increased with concentration. Significant reductions in FDF and subsequent fruit drop occurred 10 to $14 \mathrm{~d}$ after application. In contrast, reductions in FDF and fruit drop occurred within 3 to $5 \mathrm{~d}$ following applications of CMN-pyrazole sprays (Holm and Wilson, 1977). Fruit ethylene production associated with the abscission activity is also delayed with metsulfuron-methyl; treated fruit began producing ethylene 7 to $10 \mathrm{~d}$ after application (Burns et al., 1999), whereas ethylene production began 2 to $3 \mathrm{~d}$ following $\mathrm{CMN}$ pyrazole application (Holm and Wilson, 1977). Rate of fruit loosening induced by an abscission material is an important consideration 
when implementing a successful abscission management strategy. Longer periods between application and optimum fruit loosening allow for harvest to be delayed by unpredictable weather conditions or other management factors, but may compromise fruit quality.

The FDF of untreated fruit was variable, but changed only slightly throughout the harvest season (Fig. $3 \mathrm{~A}$ ). Following some natural loosening associated with improving fruit maturity during Feb. and March (Fig. 2), FDF of mature oranges increased slightly during April and May. This effect was described earlier as natural tightening that coincides with fruit set and early development of the new crop (Clark and Wilson, 1975; Wheaton et al., 1977). Response to metsulfuron-methyl varied strongly, however. Applications of metsulfuron-methyl prior to bloom markedly reduced FDF. Immediately after bloom, metsulfuron-methyl became less effective at reducing FDF and increasing fruit drop. This "less-responsive period" (Holm and Wilson, 1976, 1977; Wheaton et al., 1977) persisted for 4 to 6 weeks after bloom. After this time, metsulfuron-methyl again became effective at reducing FDF and increasing mature fruit drop. Less drop of leaves and young fruit was also measured during the period following bloom, when shoots and fruit are developing on the tree. Rapidly growing meristematic regions and developing seeds are rich sources of auxin (Davies, 1995), which reduces the ability of organs to abscise when treated with ethylene or an abscission material (Brown, 1997). When auxin concentrations fall below a critical level, ethylene regains the ability to cause abscission. Plummer et al. (1991) measured large concentrations of auxin and abscisic acid in 'Valencia' leaves during the "less-responsive period" after bloom. This suggests that levels of hormones, particularly auxin, may influence the sensitivity and response of citrus fruit and leaves to abscission materials during the "less-responsive period." Follow-up experiments are under way to determine auxin levels around the abscission zone and how they affect fruit ethylene production in response to CMN-pyrazole during that period.

Phytotoxicity, manifested as twig dieback and defoliation, was a problem with metsulfuron-methyl applications throughout the harvest season. Sulfonylureas inhibit acetolacetate synthase, a key enzyme in the biosynthesis of branched chain amino acids (LaRossa and Schloss, 1984), thereby adversely altering amino acid metabolism (Höfgen et al., 1995); thus, their import and incorporation into rapidly growing tissues, such as branch termini, may be inhibited. Although citrus fruit treated with metsulfuronmethyl produce more ethylene (Burns et al., 1999), the reason for this is unknown. The timing of ethylene production after sulfonylurea application suggests that a delayed re- sponse to wounding, as well as additional mechanisms, such as steady accumulation of the ethylene precursor methionine, may contribute to fruit ethylene evolution.

The effectiveness and reliability of mechanical harvesting equipment have improved over the last two decades (Whitney, 1995). This prompted us to assess the benefit of metsulfuron-methyl on fruit recovery with these systems. Excessive phytotoxicity associated with 1 and $2 \mathrm{mg} \cdot \mathrm{L}^{-1}$ eliminated these treatments as commercially viable and only sprays of $0.5 \mathrm{mg} \cdot \mathrm{L}^{-1}$ metsulfuron-methyl were used to compare fruit removal with $\mathrm{CMN}$ pyrazole-treated trees. Without abscission materials, total fruit removal ranged between $80 \%$ and $88 \%$. Average fruit removal improved $10 \%$ to $12 \%$ when abscission materials were applied before and after the "less-responsive period." Similar improvements in fruit recovery were reported by Whitney et al. (1986), although loss of young developing fruit significantly reduced subsequent yields with some trunk shakers. In our study, shake time was adjusted to $5 \mathrm{~s}$ and loss of young developing fruit remained low. Only the application of $100 \mathrm{mg} \cdot \mathrm{L}^{-1} \mathrm{CMN}$-pyrazole was effective in increasing fruit removal during the "less- responsive period" (7.5\%). Only a critical $17 \%$ to $35 \%$ reduction in FDF was necessary to significantly improve fruit removal; further reductions in FDF had no effect. In 1996-97, the on-tree value of hand-harvested Florida processing oranges was $\$ 834$ million (Florida Agricultural Statistics Service, 1998). A $10 \%$ to $12 \%$ reduction in fruit removal using this particular harvest system without abscission materials could mean a substantial loss of revenue if mechanisms were not in place to recover the remaining fruit. Other harvest systems should be evaluated to determine the impact of abscission materials on their harvesting efficiencies.

Although metsulfuron-methyl was effective in inducing abscission even during the "less-responsive period" of harvest, problems with specificity and phytotoxicity eliminate it as a commercially viable abscission agent for citrus. In follow-up work, we reduced the concentration to $0.25 \mathrm{mg} \cdot \mathrm{L}^{-1}$ a.i. but were unable to achieve acceptable fruit loosening. In contrast, $\mathrm{CMN}$-pyrazole loosened mature fruit selectively and overcame the "less-responsive period" at concentrations below those previously reported $\left(300-500 \mathrm{mg} \cdot \mathrm{L}^{-1}\right.$; Clark and Wilson, 1975). Although CMN-pyrazole continues to be the most effective and selective abscission material for citrus, it will probably be used only for experimental purposes because of toxicological concerns.

\section{Literature Cited}

Biggs, R.H. and S.V. Kossuth. 1980. Modeling the effectiveness of Release as a citrus harvest aid for 'Valencia' fruits. Proc. Florida State Hort. Soc. 93:301-305.

Brown, G.K. 1998. Florida citrus can be mechanically harvested. Amer. Soc. Agr. Eng. meeting presentation No. 981091, Orlando, Fla., 12-16 July 1998.

Brown, K.M. 1997. Ethylene and abscission. Physiol. Plant. 100:567-576.

Burns, J.K., U. Hartmond, and W.K. Kender. 1999. Acetolactate synthase inhibitors increase ethylene production and cause fruit drop in citrus. HortScience 34:908-910.

Clark, R.K. and W.C. Wilson. 1975. The effect of several adjuvants on the abscission activity of Release with 'Valencia' orange. Proc. Florida State Hort. Soc. 88:100-103.

Davies, P.J. 1995. The plant hormones: Their nature, occurrence, and functions. In: P.J. Davies (ed.). Plant hormones. Physiology, biochemistry and molecular biology. $2^{\text {nd }}$ ed. Kluwer Academic, Dordrecht, The Netherlands.

Florida Agricultural Statistics Service. 1998. Citrus Summary 1996-1997. Orlando, Fla.

Höfgen, R., B. Laber, I. Schüttke, A.-K.. Klonus, W. Streber, and H.-D. Pohlenz. 1995. Repression of acetolactate synthase activity through antisense inhibition. Plant Physiol. 107:469-477.

Holm, R.E. and W.C. Wilson. 1976. Loss in the capacity of 'Valencia' oranges treated with abscission materials to produce ethylene and fruit loosening during the regreening period. Proc. Florida State Hort. Soc. 89:35-38.

Holm, R.E. and W.C. Wilson. 1977. Ethylene and fruit loosening from combinations of citrus abscission compounds. J. Amer. Soc. Hort. Sci. 192:576-579.

Kender, W.J., U. Hartmond, and J.K. Burns. 1999. Fruit abscission and leaf drop in citrus cultivars treated with metsulfuron-methyl. HortTechnology 9:412-416.

LaRossa, R.A. and J.V. Schloss. 1984. The sulfonylurea herbicide sulfometuron is an extremely potent and selective inhibitor of acetolactate synthase in Salmonella typhimurium. J. Biol. Chem. 259:8753-8757.

Plummer, J.A., M.G. Mullins, and J.H. Vine. 1991. Seasonal changes in endogenous ABA and IAA and the influence of applied ABA and auxin in relation to shoot growth and abscission in 'Valencia' orange [Citrus sinensis (L.) Osbeck]. J. Plant Growth Regul.10:139-151.

Wardowski, W., J. Whigham, W. Grierson, and J. Soule. 1995. Quality tests for Florida citrus. Univ. Florida Coop. Ext. Serv. Bul. AP-99:17.

Wheaton, T.A., W.C. Wilson, and R.E. Holm. 1977. Abscission response and color changes of 'Valencia' oranges. J. Amer. Soc. Hort. Sci. 102:580-583.

Whitney, J.D. 1995. A review of citrus harvesting in Florida. Proc. Citrus Eng. Conf. 41:33-60.

Whitney, J.D., D.B. Churchill, and S.L. Hedden. 1986. A five-year study of orange removal with trunk shakers. Proc. Fla. State Hort. Soc. 99:40-44.

Whitney, J.D. and R.C. Harrell. 1989. Status of citrus harvesting in Florida. J. Agr. Eng. Res. 42:285-299.

Wilcox, M. and J.B. Taylor. 1996. Transfer: A new abscission agent. Proc. Intl. Soc. Citricult. 2:1013-1016.

Wilcox, M. and J.B. Taylor. 1997. Citrus abscission at very low application rates. Proc. Interamer. Soc. Trop. Hort. 41:141-151. 